\title{
There once was a Woman
}

\section{Norma Battle}

There WAS ONCE a woman who sat perched on a tree. Like a bird with a song she would call out into the night. Her sweet melody would float into the ears of the townsmen, melting the hardest of hearts and arousing them from the deepest slumber. Men of all ages were mesmerised by her sound. A sound that promised to fulfil every desire. Unaware of what was happening to them they followed her song. Upon seeing her, though, the glaze over their eyes was violently removed. The moonlight revealed not a woman of desire with supple breasts and a heart shaped mouth, but an old toothless woman like a vulture with a deafening squawk. She swooped on these men, her breasts dragging along the ground, her mouth omitting a foul odour that brought down her prey. Their struggle was in vain. She consumed them.

This story was told to Noah by her mother, who was told it by her mother, who was told it by her mother. Noah's mother loved telling this story, which she would always end with 'and that's why you shouldn't wish for large breasts!' On her thirteenth birthday Noah spent the morning staring at her boyish chest, willing it to grow. Her mother approached her. In the lilac coloured bathroom (her mother's obsession with all things lilac was entertained by an obedient husband who'd installed the hideous coloured bathtub himself) she placed her hands firmly on Noah's shoulders and forced her to sit. Noah sat wishing she had worn pants, she felt the cold right to her bones. It was then that her mother felt it was time to elaborate on the story she loved telling Noah over and over. Matter-offactly she stated that large breasted women could not be trusted and the men around them required a close eye. For breasts spilled out of blouses like fresh milk out of ornate jugs, tempting strong men, young and old alike. 
At school the following week, Noah noticed a newly endowed Natalie Borg prancing around her secretly beloved Ben Spence. His eyes were firmly fixed on her fixtures, of this Natalie was well aware. It was at that moment a revelation hit her like a rock to the head: mother was right! From that day on Noah's choice of friends was limited to girls (and later women) who were as limited in the flesh that covered their heart and lungs as she was, and would remain. Honestly, who can trust a heart so heaped up with flesh? Not women! For they fear their sons or husbands may be led astray by the promise of a never ending supply of satisfaction. Not men! For they fear that another may steal her, promising to cherish her heart, only to cherish the flesh that covers it instead.

The women with chests like mountains, thought Noah, must be trained from girlhood by some like-sized bosom buddy, to help realise the power contained in each robust structure. Noah had been witness to their powers, many a time since she first encountered Natalie Borg in seventh grade, seeing even the most committed of men fall, hypnotised. This is why small-chested women often gave in to the alluring call of augmentation or its less invasive cousin, the push-up bra. As imposters they are not equipped with all the tricks of the trade, but they learn enough to get by: the lean in and lean over. Noah is one of the stronger ones, inspired by the conviction of her mother and her mother before her, or so she believed until the day the ad caught her eye. It offered an unbelievable discount on the 'Pamela Anderson' style at a clinic just across the road. To Noah's surprise her eyes widened for longer than she'd wish to admit, then closing them ever so tightly she remembered...

There was once a woman who sat perched on a tree. Like a bird with a song she would call out into the night. Her sweet melody would float into the ears of the townsmen, melting the hardest of hearts and arousing them from the deepest slumber. Men of all ages were mesmerised by her sound. A sound that promised to fulfil every desire. Unaware of what was happening to them they followed her song. Upon seeing her, though, the glaze over their eyes was violently removed. The moonlight revealed not a woman of desire with supple breasts and a heart shaped mouth, but an old toothless woman like a vulture with a deafening squawk. She swooped on these men, her breasts dragging along the ground, her mouth omitting a foul odour that brought down her prey. Their struggle was in vain. She consumed them. 